UDC 378.147

DOI: $10.31470 / 2415-3729-2018-8-137-150$

\title{
Features of the Professional Training Teachers' Decision- Making in the Conditions of a Competence-Oriented Education
}

\author{
Andrii Osadchyi \\ lecturer of Konotop Institute of the Sumy State University, \\ $\triangle 24$ Myru Ave., Konotop, Sumy Region, Ukraine, 41600 \\ E-mail: osadchiy220205@gmail.com \\ ORCID: 0000-0003-1568-0574
}

\section{Mykola Ivashchenko}

Doctor of Philosophy in Pedagogy (PhD), Assistant Professor,

Department of General Pedagogy and Educational Management,

Oleksandr Dovzhenko Hlukhiv National Pedagogical University

$\triangle 24$, Kyievo-Moskovska Str., Hlukhiv, Sumy Region, Ukraine, 41400

E-mail: in22@ukr.net

ORCID: 0000-0002-7006-5999

Date of receipt of the article: August 02, 2018

Article accepted for publication: November 25, 2018

\section{Особливості прийняття рішень педагогами професійного навчання в умовах компетентнісно- оріснтованої освіти}

\section{Андрій Сергійович Осадчий}

викладач Конотопського інституту

Сумський державний університет,

$\checkmark$ проспект Миру, 24, м. Конотоп, Сумська область, Україна, 41600

\section{Микола Володимирович Іващенко}

кандидат педагогічних наук, доцент

кафедра педагогіки та менеджменту освіти, 
Глухівський національний педагогічний університет ім. О. Довженка

$\triangle$ вул. Києво-Московська, 24, м.Глухів, Сумська обл., Україна, 41400

Дата надходження статті: 02 серпня 2018 p. Стаття прийнята до друку: 25 листопада 2018 р.

\section{Abstract}

The article deals with the directions of professional education development, which are related to the necessity of focusing on the labor market needs, namely the competent direction of future specialists' training, the implementation of the conceptual provisions for the standardization of professional education. The relevance of the tendency of professional education's orientation onto the modern labor market is defined in the article.

The purpose of the article is to investigate the peculiarities of the professional activity of teachers of modern vocational education and their influence on decision-making processes. The authors of the article have made an attempt to substantiate the analysis of the peculiarities of introducing a competence-oriented approach into education as one of the effective ways of its reformation and improvement.

It is identified the cause-effect character of the necessity of designing a common methodology for the formation of the specialist's competence and the urgent solution of the problem of professional education standardization. The authors have also defined the main contradiction of this process, which is seen in the lack of involving business entities, those are the customers of the future specialists' training, in the process of creating qualification standards.

The authors have noted that nowadays the activity of teachers on standardization of professional education on a competence basis becomes the main direction of the implementation of modernization reforms in education. Therefore, in order to achieve objectivity in the professional training teachers' decision-making, the authors of the article have proposed to apply ideas and methods of informationextreme intellectual technology. This method of information-extreme 
intellectual technology (IEI-technology) for data analysis is based on maximizing the information capacity of the system in the machine teaching process, grounded onto the algorithm of the informationanalytical system on the adaptation of the graduation department's study content to the labor market requirements.

The authors have made a conclusion that, minding the further development of a model of competency education associated with the transition from the general theoretical understanding of the peculiarities of constructing subject-based educational programs, situational-simulation technologies and control-measuring methods that are adequate to practical implementation with the use of modern information systems, the special attention should be paid to the creation of educational standards, according to which educational programs and educational disciplines' content will be formed, aimed at a competency rather than on material indicators.

Key words: professional training, professional education, competence-oriented education, standardization, automated information system.

\section{References}

1. Dovbysh, A. S. (2013). Intelektualni informatsiini tekhnolohii $\mathrm{V}$ elektronnomu navchanni [Intelligent information technologies in e-learning]. Sumy: Vydavnytstvo Sumskoho derzhavnoho universytetu [in Ukrainian].

2. Dovbysh, A. S., Kulik, Ye. S., Kozlov, Z. V. \& Osadchyi, A.S. (2016). Informatsiino-ekstremalne navchannia systemy otsinky yakosti navchalnoho kontentu vypuskovoi kafedry [Information-extreme teaching the system of the study content quality evaluation of the graduation department]. Radioelektronni $i$ kompiuterni systemy - Radio electronic and computer systems, 3, 7177 [in Ukrainian].

3. Kalashnikova, S. A. (2010). Kompetentnisno oriientovanyi pidkhid: bazovi poniattia ta polozhennia [Competency-oriented approach: basic concepts and provisions]. Pedahohichna osvita: teoriia $i$ praktyka. Pedahohika. Psykholohiia - Pedagogical Education: Theory and Practice. Pedagogy. Psychology, 1, 67-71 [in Ukrainian]. 
4. Kovalchuk, H. O. (2005). Aktyvizatsiia navchannia v ekonomichnii osviti [Activation of teaching in economic education]. Kyiv : KNEU [in Ukrainian].

5. Kubenko, I. M. (2010). Shcho take kompetentnist i yak yii rozumiiut $\mathrm{v}$ osviti [What is a competence and how it is understood in education]. Dodatok do elektronnoho zhurnalu "Teoriia ta metodyka upravlinnia osvitoiu» - Appendix to the journal «Theory and Methods of Education Management», 1. Retrieved from http://www.tme.umo. edu.ua/docs/Dod/1_2010/kubenko.pdf [in Ukrainian].

6. Lozovetska, V. T. (2013). Profesiine stanovlennia osobystosti $\mathrm{v}$ suchasnykh umovakh pratsi [Professional formation of a personality in modern working conditions]. Naukovyi visnyk Instytutu profesiinotekhnichnoi osvity - Scientific Bulletin of the Institute of Vocational and Technical Education, 5, 20-25.

7. Luzan, P. H., Pashchenko, T. M., Vanina, N. M., Kolisnyk, N. V. \& Mosia, I. A. (2018). Kontseptsiia standartyzatsii profesiinoi osvity [Concept of Standardization of Professional Education]. II Mizhnarodnyi sympozium» Humanitarni ta suspilni nauky v Yevropi: dosiahnennia $i$ perspektyvy» - II International Symposium «Humanities and Social Sciences in Europe: Achievements and Prospects». Niu-York, (pp 18-25). Retrieved from http://lib.iitta. gov.ua/id/eprint/712438 [in Ukrainian].

8. Luzan, P. H., Pashchenko, T. M., Vanina, N. M. \& Kolisnyk, N. V. (2018). Standartyzatsiia profesiinoi osvity na osnovi kompetentnisnoho pidkhodu [Standardization of vocational education on the basis of competence approach]. ScienceRise, 5(25), 32-35 [in Ukrainian].

9. Pashchenko, T. M. (2018). Hotovnist pedahohichnykh pratsivnykiv do standartyzatsii pidhotovky molodshykh spetsialistiv [Readiness of pedagogical workers to standardize the training of junior specialists]. Visnyk Hlukhivskoho natsionalnoho pedahohichnoho universytetu imeni Oleksandra Dovzhenka - Bulletin of the Glukhiv National Pedagogical University named after Alexander Dovzhenko. Pedagogical sciences. Pedahohichni nauky, 2 (37), 10-16 [in Ukrainian].

10. Petruk, V. A. (2011). Kompetentnisno oriientovanyi pidkhid u protsesi fundamentalnoi pidhotovky maibutnikh fakhivtsiv 
tekhnichnoho profiliu [A competency-oriented approach in the process of the future technical specialists fundamental training]. Suchasni informatsiini tekhnolohii ta innovatsiini metodyky navchannia $u$ pidhotovtsi fakhivtsiv: metodolohiia, teoriia, dosvid, problemy Modern Information Technologies and Innovative Methods of Teaching in the Training of Specialists: Methodology, Theory, Experience, Problems, 27, 446-450.

11. Dobroskok, I. I. et al (2016). Profesiina osvita : teoretychni ta prykladni aspekty formuvannia kompetentnosti maibutnikh fakhivtsiv [Professional education: theoretical and applied aspects of forming the future specialists competency] (Part 1). PereiaslavKhmelnytskyi : FOP Dombrovska Ya. M.

\section{Вступ}

Соціально-економічні зміни в Україні суттєво впливають на ринок праці. Тенденція орієнтації професійної освіти на сучасний ринок праці диктує нові вимоги до процесу та результату підготовки випускників вищих навчальних закладів, які у своїй майбутній трудовій діяльності мають забезпечувати компетентнісну спрямованість працівника не стільки на виконання певного завдання, скільки на вміння вирішувати проблеми, орієнтуватися в сучасних умовах. Виникає потреба надавати перевагу предметам, що розвивають інтелектуальні здібності, ініціативність, пристосовуваність і впевненість для роботи в сучасних умовах (Кубенко, 2010), та своєчасно приймати рішення щодо зміни змісту навчальних дисциплін професійного спрямування.

У своїх дослідженнях вітчизняні й зарубіжні теоретики та практики (В. Андрущенко, С. Батишев, М. Свтух, С. Гончаренко, I. Доброскок, Дж. Зантворт, М. Згуровський, I. Зязюн, Г. Ковальчук, В. Кремень, Н. Кузьміна, М. Лазарєв, В. Луговий, Л. Лук'янова, С. Ніколаєнко, Н. Ничкало, В. Радкевич, С. Сисоєва, О. Савченко та інші) особливу увагу приділяють методологічним аспектам розвитку професійної освіти, проблемам стандартизації підготовки майбутніх фахівців. Питання компетентнісного підходу та компетентнісно орієнтованої освіти розроблені у публікаціях 
В. Байденко, Н. Бібік, І. Кубенка, С. Калашнікової, В. Лугового, П. Лузана, О. Овчарук, О. Пометун, С. Ракова, О. Савченко, В. Свистуна, А. Хуторського, В. Ягупова та інших.

Мета статті - дослідити особливості професійної діяльності педагогів сучасної професійної освіти та їх вплив на процеси прийняття рішень.

\section{Матеріал і методи дослідження}

Для проведення дослідження було використано низку методів наукового пошуку, зокрема - аналіз, синтез, узагальнення та систематизація наукової літератури.

\section{Результати та їх обговорення}

3 огляду на сучасний ринок праці пріоритетним завданням професійної освіти $€$ своєчасне дослідження теоретичних та практичних напрацювань в Україні та світі, використання отриманих результатів у процесі прийняття рішень майбутніми викладачами закладів професійної освіти щодо добору змісту, форм, методів та засобів навчання.

У зв'язку $з$ цим особливої актуальності набуває проблема визначення сутності компетентнісного підходу в умовах компетентнісно орієнтованої освіти. Компетентнісно орієнтований підхід до формування змісту освіти на сьогодні набув статусу концептуального орієнтиру у світі. Нині у багатьох європейських країнах результати навчання базуються на оволодінні учнями необхідними компетентностями. Засновниками компетентнісно орієнтованого підходу $є$ Лайн Спенсер і Сайн Спенсер, які 3 початку 70-х років XX ст. проводили дослідження щодо ідентифікації та з'ясування значення компетенцій в управлінні персоналом (Калашнікова, 2010:67).

Запровадження в освіту компетентнісно орієнтованого підходу розглядають як один із дієвих шляхів іiі реформування та вдосконалення (Калашнікова, 2010:67). Поняття «компетентнісна освіта» виникло у США у 80-х - початку 90-х років, коли в процесі вивчення досвіду роботи видатних учителів було здійснено спробу визначити компетентності як освітній результат. Сьогодні фахівці США визначають три основні компоненти в компетентнісній освіті: формування знань, умінь і цінностей особистості (Кубенко, 2010). 
Популярність і поширення компетентнісного підходу в Україні та світі зумовлено орієнтацією на кінцевий результат освітнього процесу та спрямування на формування у випускника готовності ефективно зорганізовувати внутрішні й зовнішні ресурси для досягнення поставленої мети. Визначення компетентностей, які мають бути універсальними за своїм характером i мірою застосування, $€$ актуальним аспектом компетентнісно орієнтованої освіти (Петрук, 2011:446).

Інакше кажучи, одна з головних проблем компетентнісного підходу - створення загальноприйнятої методики формування компетентності фахівця i визначення адекватних засобів іiі реалізації - актуалізує проблему стандартизації професійної освіти.

За цих умов стандартизацію професійної освіти слід розглядати як процедуру встановлення нормативних вимог кваліфікаційних стандартів до освітніх результатів (компетентностей) випускників закладів професійної освіти. Ця процедура забезпечує перманентне зіставлення навчальних досягнень учнів, студентів з цілями їх компетентнісно орієнтованої підготовки задля іiі корекції, гарантує досягнення належних рівнів якості професійної підготовки фахівців у професійних навчальних закладах засобами інноваційності змісту та технологій навчання i сприяє конвертованості рівнів професійної освіти всередині держави та за ii межами (Лузан, Пащенко, Ваніна \& Колісник, 2018).

Однак, зважаючи на те, що компетентність $\epsilon$ багатофункціональним поняттям, для іi формування необхідні певні організаційно-педагогічні умови, які б дозволили викладачу моделювати ту чи іншу реальну ситуацію, а також ефективні засоби контролю діяльності студента у цьому середовищі (Петрук, 2011:446).

Зважаючи на сказане вище, зазначимо, що формування кваліфікаційних стандартів для випускників закладів професійної освіти має відбуватися відповідно до динамічної технологізації та інформатизації виробництва, потреби вдосконалення функціонального поля професійної діяльності. Тобто, якщо ринкові умови діяльності передбачають підготовку особистості, здатної до самостійного прийняття професійних рішень підчас 
виконання тих чи інших завдань, а роботодавці вважають, що особистість у певній галузі діяльності повинна бути компетентною і вміти системно вдосконалювати професійні знання та вміння, гнучко застосовувати свій професійний потенціал відповідно до тих чи інших умов праці, вміти працювати в групі, брати відповідальність за результати власної праці (Лозовецька, 2013:4), то формування кваліфікаційних стандартів має відбуватися 3 активним залученням роботодавців.

Натомість у дослідженні групи авторів під керівництвом П. Лузана (Лузан, Пащенко, Ваніна, Колісник, \& Мося, 2018) зазначено, що одним 3 основних чинників, що гальмують стандартизацію освіти, $€$ недостатня участь суб'єктів господарювання у розв'язанні завдань професійної освіти. Тому до процесу розроблення стандартів слід долучитися i педагогам, які у своїй професійній діяльності мають ці стандарти реалізовувати. До того ж у Законах України «Про освіту», «Про вищу освіту» наголошується, що саме завдяки діяльності педагога реалізується державна освітня політика та забезпечується якість освіти (Професійна освіта..., 2016:210).

Безумовно, якість професійної підготовки майбутніх молодших спеціалістів значною мірою визначається готовністю педагогів до стандартизації професійної освіти молодших спеціалістів у коледжах і технікумах. Тому діяльність педагогів зі стандартизації професійної освіти на компетентнісній основі стає на сьогоднішній день основним вектором реалізації модернізаційних реформ в освіті і одним із суттєвих напрямів переходу до моделі інноваційного розвитку України в цілому (Пащенко, 2018).

Нині практично в усіх галузях підготовки чітко простежується невідповідність предметів навчальної діяльності та майбутньої професійної діяльності. Подолати цю суперечність пропонується реалізацією знаково-контекстного типу навчання, згідно з яким основною одиницею роботи викладачів і студентів стає професійна ситуація у своїй предметній i соціальній визначеності. В оптимальному варіанті контекстне навчання $€$ професійно орієнтованим, коли всі знання набуваються лише 
в контексті майбутньої професійної діяльності, а все інше вилучається зі змісту навчання (Ковальчук, 2005:6).

Суттєвим фактором, що впливає на якість освіти, є зміст та наповнення контенту як окремих навчальних модулів, так i навчальних дисциплін у цілому. Тому європейські рамкові освітні стандарти, спрямовані на вирішення проблеми оцінювання якості освіти, суттєву увагу приділяють відповідності навчального контенту вимогам ринку праці (Довбиш, Кулік, Козлов \& Осадчий, 2016).

Зважаючи на закордонний досвід та ситуацію у вітчизняній освітній галузі, в умовах компетентнісно орієнтованої освіти виникає необхідність прийняття педагогами рішень стосовно своєчасної заміни контентного наповнення навчальних дисциплін відповідно до економічної ситуації на ринку праці та умов сучасного виробництва. 3 метою об’єктивного оцінювання рівня відповідності навчального контенту вимогам ринку праці постає потреба запровадження сучасних інформаційних систем. Аналіз наявних інформаційних систем оцінювання якості навчального контенту показав, що в більшості випадків вони аналізують кількісні показники, що опосередковано виявляють якість навчального контенту. Основними недоліками їх використання $\epsilon$ те, що вони не забезпечують у режимі моніторингу зворотного зв'язку між випусковою кафедрою, роботодавцями та студентами, $\epsilon$ негнучкими i, головне, не здатні автоматично формувати базу знань. Тому на практиці аналіз якості навчального процесу вимагає використання значних часових i викладацьких ресурсів i не гарантує об’єктивності результатів оцінювання.

Основним шляхом подолання цих недоліків $є$ перехід від експертних систем оцінювання якості навчального процесу до систем підтримки прийняття рішень (СППР), здатних аналізувати i надавати рекомендації користувачам (Довбиш, Кулік, Козлов \& Осадчий, 2016).

Одним із перспективних шляхів вирішення цієї проблеми $\epsilon$ застосування ідей i методів інформаційно-екстремальної інтелектуальної технології (IEI-технологіï) аналізу даних, що грунтується на максимізації інформаційної спроможності системи в процесі машинного навчання (Довбиш, 2013). В основу

(C) Андрій Сергійович Осадчий

(с) Микола Володимирович Іващенко 
зазначеної IEI-технології аналізу даних покладено алгоритм інформаційно-аналітичної системи адаптації навчального контенту випускової кафедри до вимог ринку праці.

Працездатність розроблених алгоритмів перевірена шляхом зіставлення результатів, отриманих у процесі машинного оцінювання різних якісних рівнів навчального контенту випускової кафедри комп'ютерних наук Сумського державного університету, 3 результатами проведеного опитування незалежних провідних фахівців ІТ-компаній. У процесі дослідження сформульовано висновок, що для побудови безпомилкових за навчальною вибіркою вирішальних правил необхідно продовжувати здійснювати оптимізацію параметрів функціонування, що впливають на функціональну ефективність роботи інформаційноаналітичної системи. 3 метою оцінювання контенту окремих навчальних дисциплін необхідно переходити до ієрархічної структури даних (Довбиш, Кулік, Козлов, \& Осадчий, 2016).

\section{Висновки}

Вважаємо, що зважаючи на подальше розроблення моделі компетентнісної освіти, пов'язаної 3 переходом від загальнотеоретичного уявлення про особливості побудови предметних освітніх програм, адекватних їм ситуаційномоделювальних технологій i контрольно-вимірювальних методів до практичної реалізації 3 використанням сучасних інформаційних систем, особливу увагу слід приділяти створенню освітніх стандартів, відповідно до яких будуть сформовані освітні програми та контентне наповнення навчальних дисциплін, орієнтовані на компетентність, а не на показники матеріалу (Кубенко, 2010).

Перспективним напрямом досліджень може бути пошук варіативних шляхів реалізації компетентнісно орієнтованої освіти 3 використанням можливостей сучасних експертних інформаційних систем та систем підтримки прийняття рішень.

\section{Література}

1. Довбиш А. С. Інтелектуальні інформаційні технології в електронному навчанні. Суми: Видавництво Сумського державного університету, 2013. 172 с. 
2. Довбиш А. С., Кулік Є.vС., Козлов 3. В., Осадчий А. С. Інформаційно-екстремальне навчання системи оцінки якості навчального контенту випускової кафедри. Радіоелектронні $i$ комп ’ютерні системи. Суми, 2016. № 3. С. 71-77.

3. Калашнікова С. А. Компетентнісно орієнтований підхід: базові поняття та положення. Педагогічна освіта: теорія $i$ практика. Педагогіка. Психологія. Київ, 2010. № 1. С. 67-71.

4. Ковальчук Г. О. Активізація навчання в економічній освіті : навч. посіб. 2-ге вид., доп. Київ : КНЕУ, 2005. 298 с.

5. Кубенко I. М. Що таке компетентність і як іï розуміють в освіті. Додаток до електронного журналу «Теорія та методика управління освітою». Київ, 2010. № 1. - URL: http://www.tme.umo. edu.ua/docs/Dod/1_2010/kubenko.pdf (дата звернення: 31.01.2019).

6. Лозовецька В. Т. Професійне становлення особистості в сучасних умовах праці. Науковий вісник Інституту професійнотехнічної освіти. Київ, 2013. № 5. С. 20-25.

7. Лузан П. Г., Пащенко Т. М., Ваніна Н. М., Колісник Н. В., Мося І. А. Концепція стандартизації професійної освіти. II Міжнародний симпозіум» Гуманітарні та суспільні науки в Свропі: досягнення $i$ перспективи». Нью-Йорк, 2018. C. 18-25. - URL: http://lib.iitta.gov.ua/id/eprint/712438 (дата звернення: 31.01.2019).

8. Лузан П. Г.,

Пащенко Т. М.,

Ваніна Н. М., Колісник Н. В. Стандартизація професійної освіти на основі компетентнісного підходу. ScienceRise. Харків, 2018. № 5(25). C. $32-35$.

9. Пащенко Т. М. Готовність педагогічних працівників до стандартизації підготовки молодших спеціалістів. Вісник Глухівського національного педагогічного університету імені Олександра Довженка. Педагогічні науки. Глухів, 2018. № 2 (37). C. $10-16$.

10. Петрук В. А. Компетентнісно орієнтований підхід у процесі фундаментальної підготовки майбутніх фахівців технічного профілю. Сучасні інформаційні технологї та інноваційні методики навчання у підготовці фахівців: методологія, теорія, досвід, проблеми, 2011. № 27. С. 446-450. 
11. Професійна освіта : теоретичні та прикладні аспекти формування компетентності майбутніх фахівців : колективна монографія ; част. 1. / I. І. Доброскок та ін. ; керівник авторського колективу I. І. Доброскок. Переяслав-Хмельницький : ФОП Домбровська Я. М., 2016. 444 с.

Осадчий А. С., Иващенко Н. В.

\section{Особенности принятия решений педагогами профессионального обучения в условия компетентностного-ориентированного образования}

\section{Аннотация}

В статье рассмотрены направления развития профессионального образования, связанные с необходимостью ориентироваться на потребности рынка труда: компетентностная направленность подготовки будущих специалистов, реализация концептуальных положений стандартизации профессионального образования. Выявлено актуальность тенденции ориентации профессионального образования на современный рынок труда.

Предпринята попытка обоснованного анализа особенностей внедрения в образование компетентно ориентированного подхода как одного из действенных путей его реформирования и совершенствования.

Выявлено причинно-следственный характер необходимости создания общепринятой методики формирования компетентности специалиста и безотлагательного решения проблемы стандартизации профессионального образования. Основным противоречием этого процесса определено недостаточное привлечение субъектов хозяйствования, которые являются заказчиками подготовки будущих специалистов, к процессу создания квалификационных стандартов.

Сделан вывод, что деятельность педагогов по стандартизации профессионального образования на компетентностный основе на сегодняшний день выступает основным направлением 
реализации модернизационных реформ в образовании. Поэтому для достижения объективности в процессе принятия решений педагогами профессионального обучения предложено применять идеи и методы информационно-экстремальной интеллектуальной технологии.

Ключевые слова: профессиональное обучение, профессиональное образование, компетентно ориентированное образование, стандартизация, автоматизированная информационная система.

\section{Осадчий А. С., Іващенко М. В.}

\section{Особливості прийняття рішень педагогами професійного навчання в умовах компетентнісно-оріснтованої освіти}

\section{Анотація}

У статті розглянуто напрями розвитку професійної освіти, пов'язані 3 необхідністю орієнтуватися на потреби ринку праці: компетентнісна спрямованість підготовки майбутніх фахівців, реалізація концептуальних положень стандартизації професійної освіти. Виявлено актуальність тенденції орієнтації професійної освіти на сучасний ринок праці.

Здійснено спробу обгрунтованого аналізу особливостей запровадження в освіту компетентнісно орієнтованого підходу як одного із дієвих шляхів іiі реформування та вдосконалення.

Виявлено причиново-наслідковий характер необхідності створення загальноприйнятої методики формування компетентності фахівця та невідкладного вирішення проблеми стандартизації професійної освіти. Основною суперечністю цього процесу визначено недостатнє залучення суб'єктів господарювання, які $є$ замовниками підготовки майбутніх фахівців, до процесу створення кваліфікаційних стандартів.

Зроблено висновок, що діяльність педагогів зі стандартизації професійної освіти на компетентнісній основі стає на сьогоднішній день основним напрямом реалізації модернізаційних 
реформ в освіті. Тому для досягнення об’єктивності в прийнятті рішень педагогами професійного навчання запропоновано застосовувати ідеї та методи інформаційно-екстремальної інтелектуальної технології.

Ключові слова: професійне навчання, професійна освіта, компетентнісно орієнтована освіта, стандартизація, автоматизована інформаційна система. 